\title{
Peach orchard evapotranspiration in a sandy soil: Comparison between eddy covariance measurements and estimates by the FAO 56 approach
}

\author{
T.A. Paço*, M.I. Ferreira, N. Conceição \\ Universidade Técnica de Lisboa, Instituto Superior de Agronomia, Dep. Eng. Rural, Tapada da Ajuda 1349-017, Lisboa, Portugal
}

\section{A R T I C L E I N F O}

\section{Article history:}

Accepted 11 May 2006

Published on line 5 July 2006

Keywords:

Peach

Prunus persica

Crop coefficient

Eddy covariance

\begin{abstract}
A B S T R A C T
The evapotranspiration from a 3 to 4 years old drip irrigated peach orchard, located in central Portugal, was measured using the eddy covariance technique during two irrigation seasons, allowing the determination of crop coefficients. These crop coefficient values differed from those tabled in FAO Irrigation and Drainage Paper 56. In order to improve evapotranspiration estimates obtained from FAO tabled crop coefficients, a dual crop coefficient methodology was adopted, following the same guidelines. This approach includes a separation between the plant and soil components of the crop coefficient as well as an adjustment for the sparse nature of the vegetation. Soil evaporation was measured with microlysimeters and compared with soil evaporation estimates obtained by the FAO 56 approach. The FAO 56 method, using the dual crop coefficient methodology, was also found to overestimate crop evapotranspiration. During 2 consecutive years, measured and estimated crop coefficients were around 0.5 and 0.7 , respectively. The estimated and measured soil evaporation components of the crop coefficient were similar. Therefore, the overestimation in evapotranspiration seems to result from an incorrect estimate of the plant transpiration component of the crop coefficient. A modified parameter to estimate plant transpiration for young, yet attaining full production, drip irrigated orchards is proposed based on field measurements. The method decreases the value of basal crop coefficient for fully developed vegetation. As a result, estimates of evapotranspiration were greatly improved. Therefore, the new approach seems adequate to estimate basal crop coefficients for orchards attaining maturity established on sandy soils and possibly for other sparse crops under drip irrigation conditions.
\end{abstract}

(C) 2006 Elsevier B.V. All rights reserved.

\section{Introduction}

Agriculture represents the major water consumption at a global scale and can be responsible for a misuse of water, either by a low efficiency of irrigation or by an inadequate irrigation scheduling. When irrigation requirements are overestimated, a loss of water occurs, resulting in higher production costs and negative environmental impacts. Water scarcity and the ways of saving water are increasingly relevant, stressing the need to estimate plant water requirements with accuracy.

The use of reference evapotranspiration $\left(\mathrm{ET}_{0}\right)$ and crop coefficients $\left(K_{c}\right)$ to estimate crop evapotranspiration is commonly used in irrigation scheduling for a large group of crops. Doorenbos and Pruitt (1977), between others, have addressed this useful and convenient approach, as alternative

\footnotetext{
* Corresponding author. Tel.: +351 213653335; fax: +351 213621575.

E-mail address: tapaco@isa.utl.pt (T.A. Paço).
} 
evapotranspiration field measurements are more time consuming and need technical facilities that are not always available.

The methodology described in Doorenbos and Pruitt (1977) has been improved by Allen et al. (1998) (FAO Drainage and Irrigation Paper 56), with a modification in the calculation of $\mathrm{ET}_{0}$ and the presentation of two alternative procedures for the determination of crop evapotranspiration $\left(\mathrm{ET}_{\mathrm{c}}\right)$. From the two possible calculation procedures to estimate $\mathrm{ET}_{\mathrm{c}}$, the first one uses a single $K_{c}$, combining crop transpiration and soil evaporation effects and is used to calculate $\mathrm{ET}_{\mathrm{c}}$ for weekly or longer periods. The second, proposes an approach based on the separation between the plant transpiration and the soil evaporation components in the crop coefficient (basal crop coefficient and soil evaporation coefficient, respectively), as already suggested in former studies (Ritchie, 1972; Tanner and Jury, 1976; Kanemasu et al., 1979). The $K_{c}$ is obtained combining the soil evaporation coefficient $\left(K_{e}\right)$, which describes evaporation from the soil, and the basal crop coefficient $\left(K_{\mathrm{cb}}\right)$, which describes plant transpiration. The $K_{\mathrm{cb}}$ is defined by Burman et al. (1980) and Wright (1982) as the crop coefficient attained under minimal soil evaporation, assuming non-limiting available soil water for plant growth or transpiration. $\mathrm{ET}_{\mathrm{C}}$ is computed as

$\mathrm{ET}_{\mathrm{c}}=\left(\mathrm{K}_{\mathrm{cb}}+K_{\mathrm{e}}\right) \mathrm{ET}_{0}=K_{\mathrm{c}} \mathrm{ET}_{0}$.

This procedure, using the separate estimates of the plant and soil components of the crop coefficient, would allow an independent observation of both components and the comparison between them.

Some studies have compared the results obtained using the approach described by Allen et al. (1998) with those resulting from other methodologies. For example, Casa et al. (2000) applied the Bowen ratio method in a linseed crop and found a good agreement. In another study, Allen (2000) applied his methodology to an extensive multiple-cropped surface, which included some peach orchards, and compared the results with those obtained by remote sensing. Results have shown that the FAO 56 approach overestimated evapotranspiration by more than $20 \%$ for some situations (Allen, 2000). Lascano (2000) also observed that the method could not describe adequately daily ET for an irrigated cotton crop, showing a certain lack of sensibility to capture the dynamic nature of the evaporation process. A study by Dragoni et al. (2004), in an apple orchard, showed a significant overestimation (over 15\%) of basal crop coefficients by the FAO 56 method compared to measurements (sap flow). Other studies in woody crops (Testi et al., 2004; Rana et al., 2005, for olive and citrus orchards, respectively) found that crop coefficients vary significantly during the growth season being impossible to assume a constant value, as suggested by Allen et al. (1998). Therefore, some limitations should be expected in the application of the FAO 56 approach. When accurate water use quantification is needed, it might be useful to check the procedure against ET measurements. This crosschecking may be important particularly at a regional scale, before adopting the FAO 56 procedure to estimate ET for specific crops.

Peach crop coefficients have been previously measured in central Portugal, in 1994, in a sandy soil orchard (4 year old, LAI = 1.4) with micro-sprinkler irrigation (Ferreira et al., 1996, 1997), yielding $K_{c}$ values between 0.4 and 0.6. These values are lower than those referred for peach by Doorenbos and Pruitt (1977). For the site of the present experiment, differences between measured and tabled crop coefficients were evident, as shown by Snyder et al. (2000) for a shorter period. The objective of this study was to compare values of the crop coefficient measured in the field on a seasonal basis with estimates obtained by the improved FAO methodology. The eddy covariance technique used as a reference (to adjust sap flow estimates) is regarded as an accurate technique to measure ET from tree crops, if measurement requirements and data validation procedures are observed (Baldocchi et al., 1988; Berbigier et al., 1996; Snyder et al., 2000).

\section{Materials and methods}

\subsection{The experimental site}

The experiment took place at a peach orchard in Atalaia, Montijo (latitude $38^{\circ} 42^{\prime} \mathrm{N}$, longitude $8^{\circ} 48^{\prime} \mathrm{W}$, elevation near 0 ), Portugal. The climate is temperate with cool, wet winters and hot, dry summers. Average annual rainfall is around $600 \mathrm{~mm}$ and mean air temperature around $16{ }^{\circ} \mathrm{C}$.

The peach (Prunus persica [L.] Batsch.) cultivar at the site was Silver King, a nectarine, grafted on GF 677 rootstock. The trees were planted in 1996 along a ridge about $20 \mathrm{~cm}$ high, at a $5 \mathrm{~m} \times 2 \mathrm{~m}$ spacing layout. The mean height was close to $3 \mathrm{~m}$, without considering isolated branches (taller isolated branches were at about $3.5 \mathrm{~m}$ height). The orchard was usually harvested in the beginning of June. In 1998, mean yield was 18 ton/ha. The drip irrigation system had an emitter each meter in the row (2000 emitters/ha) and the flow rate of water through each emitter was about $3.5 \mathrm{l} / \mathrm{h}$. Irrigation generally took place early in the evening and mean daily irrigation amount was typically between 4 and $5 \mathrm{~mm}$, during the observation period. The irrigation system worked properly during the experimental period, leading to a stress free plant water status, controlled by measurements of predawn leaf water potential. The wetted area following irrigation was about $6.4 \%$ of total area, being located under the canopies. The soil was sandy (haplic arenosol, according to FAO classification) with a single grain structure, resulting from regular tillage. Row orientation was $13^{\circ} \mathrm{NNE}$ and prevailing winds were from NW (Fig. 1a). The total orchard area was about 60 ha (Fig. 1b).

Ground cover (measured by a technique which accounts for the shadowed areas near solar noon) was around $29 \%$ (Conceição, 2001). The leaf area index (LAI) was estimated indirectly through the relationship between the number of leaves in the trees and the total leaf area. LAI was about 1.2 and 1.4, in 1998 and 1999 (July), respectively.

\subsection{Meteorological measurements}

Wind speed and direction, air temperature and humidity were measured at a height of $3.5 \mathrm{~m}$ above the ground. Wind speed and direction were measured by a A100R anemometer and a 


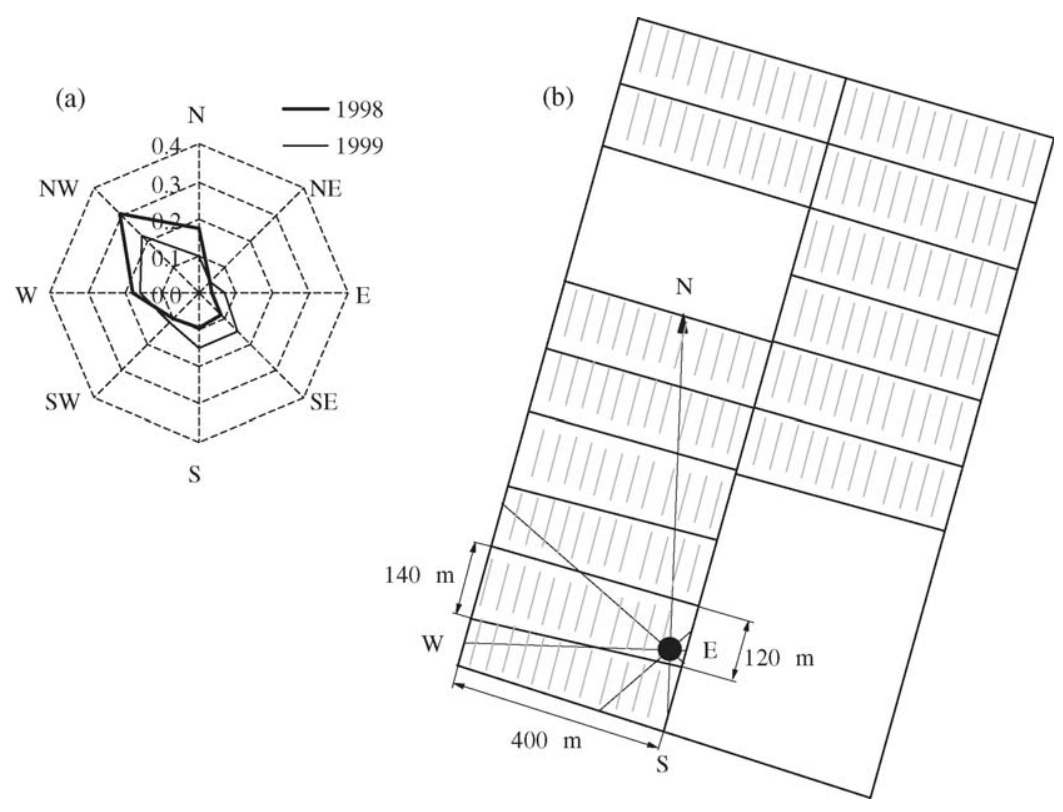

Fig. 1 - (a) Mean frequency of wind direction from June to September measured at the field plot; (b) location of the tower used for micrometeorological measurements (black circle); the two non-dashed areas were either cultivated with low crops or fallow; the remaining areas correspond to peach or plum orchards.

W200P wind vane (Vector Instruments, Rhyl, United Kingdom), respectively. A standard ventilated psychrometer (Insbruck University, Austria) was used to measure temperature and air vapour pressure deficit. The measurements were carried out during most of the irrigation season, i.e., between June and September, in 1998 and 1999.

\subsection{Soil evaporation measurements}

Soil evaporation $\left(E_{\mathrm{s}}\right)$ was measured using nine cylindrical microlysimeters, $12 \mathrm{~cm}$ deep, with $15 \mathrm{~cm}$ of internal diameter, built and used according to Daamen et al. (1993). The external cylinders of the lysimeters were disposed in a $10 \mathrm{~m}^{2}$ area (the smallest reproducible area in the plot as the spacing layout was $5 \mathrm{~m} \times 2 \mathrm{~m}$ ). Five were placed along the row, between two trees (the area wetted by irrigation) and the other four between rows (area not wetted by irrigation), near the limit of the vertical projection of the canopy (Fig. 2). The soil cores were taken from a different place every day into an internal cylinder and reinstalled inside the external cylinders at the fixed locations. Measurements were performed each half-hour during selected days. Soil evaporation was calculated as a weighted average of lysimeter values, being the weights the areas represented by each lysimeter, defined according to lysimeters location (Fig. 2). Area 1 was located between tree rows and was not irrigated $(2 \mathrm{~m} \times 4.6 \mathrm{~m})$; area 2 was associated to the middle point between two trees in the row $(0.4 \mathrm{~m} \times 0.4 \mathrm{~m})$; area 3 was located in the tree row, receiving irrigation water directly $(0.4 \mathrm{~m} \times 1.6 \mathrm{~m})$. For the area associated to each tree $\left(10 \mathrm{~m}^{2}\right), 9.2 \mathrm{~m}^{2}$ had an evaporation as measured in lysimeters $6,7,8$ and $9,0.16 \mathrm{~m}^{2}$ as measured in lysimeter 3 and $0.64 \mathrm{~m}^{2}$ as measured in lysimeters 1, 2, 4 and 5. Results were cumulated for daily values of soil evaporation.

\subsection{Eddy covariance measurements}

Sensible and latent heat fluxes were measured by the eddy covariance technique, during time series from 1 to 9 adjoining days, between days of the year (DOY) 172 (21st June) and 247 (4th September) in 1998 and between DOY 190 (9th July) and 223 (11th August) in 1999. This resulted in 42 days of measurements in 1998, from which 22 days were selected according to fetch conditions. The same procedure, applied to 1999, yielded a selection of 14 days of reliable data.

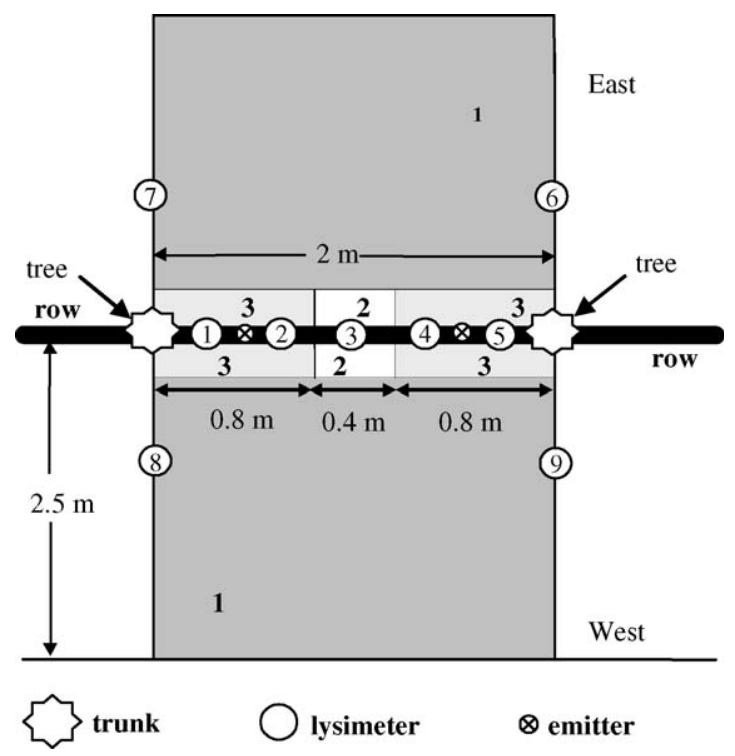

Fig. 2 - Location of the lysimeters used for measuring soil evaporation. The numbered circles represent the lysimeters, the other numbered areas represent the areas used to identify the conditions associated to lysimeters. 
Vertical wind speed, temperature and humidity fluctuations were measured by a one-dimensional sonic anemometer, a fine-wire thermocouple and a krypton hygrometer, respectively (Models CA27, 127 and KH20, Campbell Scientific, Inc., Logan, UT, USA). These instruments were installed at a height of $4.5 \mathrm{~m}$, and data stored in a datalogger (21X, Campbell Scientific Inc., Logan, UT, USA). Tower location (Fig. 1b) was selected according to dominant wind direction and fetch needs in this direction. The sampling rates were 5 and $10 \mathrm{~Hz}$ (adequation confirmed by spectral and co-spectral analysis), combined with a flux averaging period of $10 \mathrm{~min}$ and a final storage of data every $30 \mathrm{~min}$. Half-hourly measurements of latent heat flux were integrated into daily crop evapotranspiration values.

Latent heat data were corrected for density effects (Webb et al., 1980) and oxygen absorption (Tanner et al., 1993) and a footprint analysis was performed as described by Schuepp et al. (1990).

In order to check energy balance closure, soil heat flux $(G)$ and net radiation $\left(R_{n}\right)$ were measured using soil heat flux plates and a net radiometer (Model S-1 Swissteco Instruments, Oberriet, Switzerland and, for a short period in 1998, Model Schenck 8111, PH Schenck Gmbh, Vienna, Austria), respectively. Eight heat flux plates (HFT-3, Radiation and Energy Balance Systems, USA) were placed regularly along a line perpendicular to tree rows, at a depth of $5 \mathrm{~cm}$. For the determination of soil heat flux at the surface, heat storage in the soil layer above the plates was accounted for by measuring soil temperature with thermocouples and calculating soil volumetric heat capacity $\left(c_{\mathrm{v}}\right)$, using measurements of soil bulk density and water content. For the tree row area and for soil water content near field capacity, $c_{\mathrm{v}}$ was estimated as $1.65 \mathrm{MJ} \mathrm{m}^{-3} \mathrm{~K}^{-1}$ and, in the same area, but for lower water content, as $1.63 \mathrm{MJ} \mathrm{m}^{-3} \mathrm{~K}^{-1}$. For the area between rows, $c_{\mathrm{v}}$ was estimated as $1.43 \mathrm{MJ} \mathrm{m}^{-3} \mathrm{~K}^{-1}$. For periods without measurements of $G$, a relationship between $G$ and $R_{n}$ (obtained for periods with simultaneous measurements of $G$ and $R_{n}$ ) was used to estimate $G$, considering a time lag of $1 \mathrm{~h}$ between variables:

$G_{t}=0.0005 R_{n_{t+1}}^{2}+0.0874 R_{n_{t+1}}-52.59, \quad r^{2}=0.95$

Crop evapotranspiration measured by the eddy covariance technique $\left(\mathrm{ET}_{\mathrm{ec}}\right)$, was used to calculate crop coefficients as $K_{\mathrm{c} \mathrm{ec}}=\mathrm{ET}_{\mathrm{ec}} / \mathrm{ET}_{\mathrm{O}}$.

\subsection{FAO calculations for $\mathrm{ET}_{0}, \mathrm{~K}_{\mathrm{c}}$ and $\mathrm{ET}_{\mathrm{c}}$}

Reference evapotranspiration ( $\left.\mathrm{ET}_{0}\right)$, crop coefficients $\left(\mathrm{K}_{\mathrm{C}}\right)$ and crop evapotranspiration $\left(\mathrm{ET}_{\mathrm{c}}\right.$ ) were estimated daily following the guidelines provided by the FAO Irrigation and Drainage Paper 56 (Allen et al., 1998), using dual crop coefficient approach. The main steps were to identify crop growth stage (mid-season growth stage period), estimate the basal crop coefficient, estimate the soil evaporation coefficient and finally estimate the crop coefficient.

Field conditions correspond to the so-called non-typical conditions (as defined by Allen et al., 1998). The arrangement of the orchard at Atalaia differs from those listed in Allen et al. (1998), in ground cover, spacing, size and LAI of the trees (R. Allen, personal communication, 2001); values of these vari- ables are lower at the site than those considered there as standard. Therefore, an adjusted $K_{\mathrm{cb}}$, hereafter referred as $\mathrm{K}_{\mathrm{cb}}$ adj was calculated considering the orchard as a sparse vegetation. The adjustment was made based on the effective ground cover, as

$K_{\text {cbadj }}=K_{\text {c min }}+\left(K_{\text {cb full }}-K_{\text {c min }}\right) f_{\text {ceff }}^{1 /(1+h)}$

where $K_{c} \min$ is the minimum $K_{c}$ for bare soil, $K_{c b}$ full the estimated $K_{\mathrm{cb}}$ during the mid-season for vegetation having full ground cover or LAI $>3, f_{c}$ eff the effective fraction of soil surface covered or shaded by vegetation and $h$ is the plant height $[\mathrm{m}]$. The result of the above equation is limited by the selected term $f_{\text {ceff }}^{1 /(1+h)}$ (see Allen et al., 1998) as this is the one that includes more comprehensive information about the crop (R. Allen, 2001, personal communication). Values for $K_{\mathrm{cb}}$ full were taken from Allen et al. (1998) and adjusted for climate, yielding a value of 0.84 for 1998 and 0.81 for 1999. A value of 0.29 was taken for $f_{c}$ eff , as this was the fraction of ground cover measured in the orchard, at solar noon. $K_{\mathrm{c}}$ min often varies approximately between 0.15 and 0.20 but, for extended drying periods it can reduce to zero or nearly zero (Allen et al., 1998, 2005). A value of zero was used for $K_{c}$ min.

Estimates of soil evaporation and $K_{e}$ were calculated following the recommendations for daily irrigation. In this orchard, the wetted area was shaded during most of the time. However, even if this would imply some reduction in evaporation, a local advection effect was probably important due to large areas of exposed soil between rows (about 71\% at solar noon). The upper limit of $K_{e}$, established by $f_{\text {ew }} K_{c} \max$ (where $f_{\text {ew }}$ is the fraction of exposed wet soil), is then not directly applicable because, in this case, the wet soil surface is not exposed to direct sunlight, as it is covered by canopies. A value for $f_{\text {ew }}$ was derived following the suggestions of Allen et al. (1998), multiplying the fraction of soil surface wetted by irrigation $\left(f_{\mathrm{w}}\right)$ by $\left[1-(2 / 3) f_{\mathrm{c}}\right]$, for the case of drip irrigation. Considering these calculations, $f_{\text {ew }}$ was fixed at 0.05 (as $\left.f_{\mathrm{w}}=0.064\right)$.

Meteorological data collected at the site, above the orchard, were used for the estimation of $\mathrm{ET}_{0}$, although not measured in standard conditions (grass crop with a height of $0.12 \mathrm{~m}$, a surface resistance of $70 \mathrm{~s} \mathrm{~m}^{-1}$ and an albedo of 0.23 ). However, no relevant differences were found between data from the site and from the nearest three meteorological stations. Therefore, data collected locally were used, since they were freely available for a longer period.

\section{Results and discussion}

\subsection{Measurement of ET by the eddy covariance technique}

\subsubsection{Considerations on the selection of data}

At the orchard, the fetch for the SW, W, NW and N directions was about 150, 300, 500 and $545 \mathrm{~m}$, respectively (Fig. 1b). A ratio of 1:100 between height of measurements and fetch is often considered adequate for eddy covariance measurements (Tanner et al., 1988; Leclerc and Thurtell, 1990) although under some conditions a smaller fetch could be considered (Laubach et al., 1994). Within the four directions mentioned above, the 

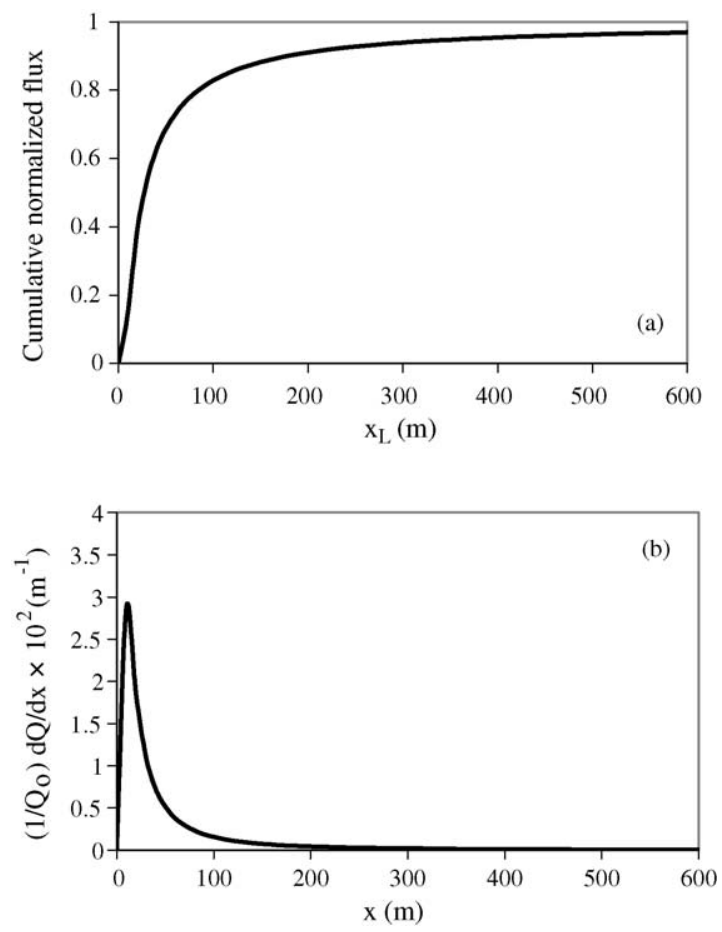

Fig. 3 - (a) Cumulative normalized flux; (b) relative flux density (one-dimensional footprint); $x$, horizontal distance between the observation point and a given point within the fluxes source region; $x_{\mathrm{L}}$, distance between the observation point and the fluxes source region limit.

height to fetch ratio was less favourable for the SW and W directions (higher than 1:100). According to the footprint analysis, an upwind distance of $150 \mathrm{~m}$ (e.g., in the SW direction) would mean that almost $90 \%$ of the fluxes sensed by the eddy covariance system come from this upwind area (Fig. 3a and Table 1). The same kind of analysis for the $\mathrm{W}$ direction indicated a percentage of $94 \%$. The footprint analysis also predicted that the measurements at $4.5 \mathrm{~m}$ height were mainly affected by fluxes coming from an upwind area at a distance of about $9 \mathrm{~m}$ (Fig. 3b). Therefore, data collected in days with dominant wind direction from SW, W, NW and N were considered reliable. Data collected in days with dominant winds from other directions were discarded, as the percentage of sensed fluxes, coming from the upwind area, dropped below $70 \%$.

\begin{tabular}{lcc}
\multicolumn{3}{c}{ Table 1 - Data selection according to footprint analysis } \\
Wind direction & Fetch $(\mathrm{m})$ & CNF \\
\hline N & 545 & 0.97 \\
NW & 500 & 0.96 \\
W & 300 & 0.94 \\
SW & 150 & 0.88 \\
S & 35 & 0.58 \\
SE & 30 & 0.53 \\
E & 25 & 0.47 \\
NE & 47 & 0.67 \\
\hline
\end{tabular}

The first 4 directions correspond to dominating wind directions in days of selected data. CNF, cumulative normalized flux.
Surface energy balance closure was checked, comparing latent heat flux (LE) and sensible heat flux $(H)$ measured by eddy covariance technique with $R_{\mathrm{n}}$ and $G$ (Fig. 4). Available energy $\left(R_{n}-G\right)$ exceeds systematically the measured fluxes $(L E+H)$ as reported, for example, by Lee and Black (1993), Simpson et al. (1998), Kustas et al. (1999), Twine et al. (2000) and Wilson et al. (2002), being the underestimation of LE + H between 10 and $30 \%$. The lack of energy balance closure is often associated with measurement errors on $R_{\mathrm{n}}$ and $G$ (Lee and Black, 1993; Wilson et al., 2002), but is not completely explained by this uncertainty, as demonstrated by Twine et al. (2000).

For the present study, the lack of closure was below $10 \%$ (Fig. 4) for all the periods of measurement. A possible $10 \%$ underestimation is considered adequate in most agricultural applications (Kizer and Elliot, 1991). A closure error of $10 \%$ is within the values commonly considered as consistent estimates of fluxes by the eddy covariance technique (Thompson et al., 1999; Twine et al., 2000). Therefore, the presented energy balance closure was considered to provide evidence for the validity of the results on latent heat flux.

\subsubsection{Measured evapotranspiration and seasonal consumption}

Measured evapotranspiration ( $\mathrm{ET}_{\mathrm{ec}}$ ) ranged from 1.4 to $3.6 \mathrm{~mm}$ /day in 1998 and from 2.1 to $3.3 \mathrm{~mm}$ /day in 1999 (Fig. 5). Mean evapotranspiration of the observed periods in 1998 and 1999 was 2.5 and $2.6 \mathrm{~mm} /$ day, respectively. The mean crop coefficient, calculated as $\mathrm{ET}_{\mathrm{ec}} / \mathrm{ET}_{0}$, was 0.5 , varying between 0.4 and 0.6 (Fig. 6).

This is in agreement with evapotranspiration and peach crop coefficients seasonal data obtained in a nearby site (Águas de Moura, Portugal) by means of transpiration measurements by the heat balance sap flow method and modelled soil evaporation (Ferreira et al., 1996); the sum was similar to eddy covariance data obtained for only 9 days (Ferreira et al., 1997). The shortness of this period enforced the need of a larger one with eddy covariance observations.

In the present study, the water use of the orchard has been quantified for the irrigation season (June-September) using a combination of techniques (eddy covariance combined with lysimetry and sap flow measurements, to adjust long term sap flow estimations, as described in Paço et al., 2004). The crop coefficient values obtained for this larger period were similar and if a mean $K_{\mathrm{c}}=0.5$ (for the whole period of measurements) is used to estimate the orchard $\mathrm{ET}_{\mathrm{c}}$, we would have $\mathrm{ET}_{\mathrm{C}}=784 \mathrm{~m}^{3} /$ ha in 1998 and $\mathrm{ET}_{\mathrm{C}}=720 \mathrm{~m}^{3} / \mathrm{ha}$ in 1999 , for the month with greater water consumption (July). For the same period, the methodology using a combination of techniques, as referred above, showed that the water requirements of the orchard were $824 \mathrm{~m}^{3} /$ ha for the first year and $732 \mathrm{~m}^{3} /$ ha for the second.

\subsection{Estimated evapotranspiration}

The tree density in the orchard was 1000 trees/ha, which can be considered a medium density (Grappadelli and Sansavini, 1998), but higher than the average density in Portugal for peach orchards (around 800 trees/ha). ${ }^{1}$ Ground cover was 0.29

${ }^{1}$ Source: Instituto Nacional de Estatística, Portugal, 1998. 

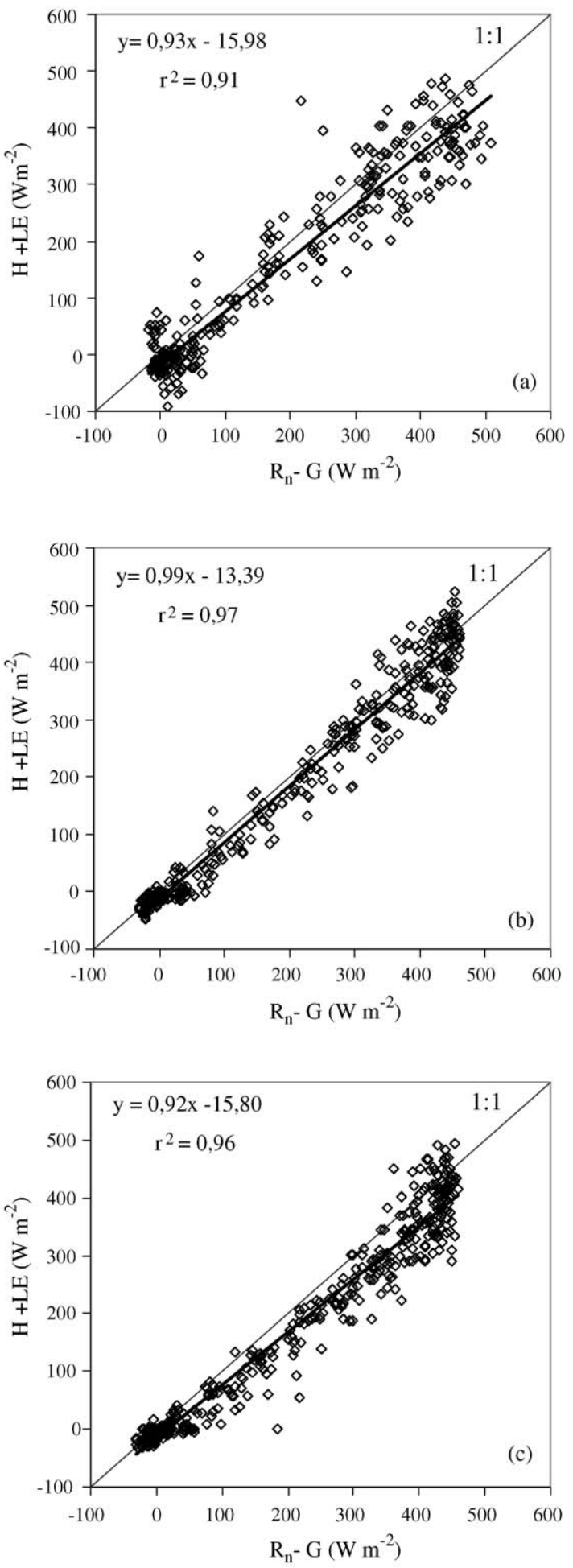

Fig. 4 - Energy balance closure with half-hourly measurements, for the period considered: (a) days of year 184, 187, 189, 190, 191, 196 and 197, eight plates system, 1998; (b) days of year 172-174, 178, 179, 205, 206, 208 and 211,1998 , using estimates of $G$ obtained from $R_{n}$ and (c) days of year 190, 191, 196, 197, 202, 203, 210-214, 1999, using estimates of $G$ obtained from $R_{n}$.

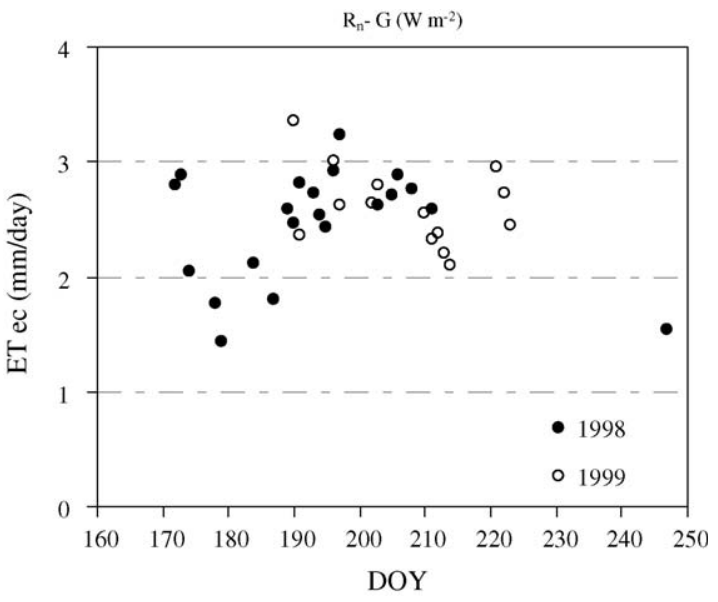

Fig. 5 - Peach evapotranspiration measured with the eddy covariance technique.

as described in Section 2.1. The adjustment procedures used in this work (for sparse crops) may be needed for other peach orchards, as medium and low densities can also be found in several regions of southern Europe (e.g., in Italy, as described in Giovannini and Monastra, 1998).

At Atalaia, the $K_{\mathrm{cb}}$ adj was estimated to be close to 0.6. The soil component, $K_{e}$, was on average 0.056 and mean soil evaporation, estimated as $\mathrm{K}_{\mathrm{e}} \mathrm{ET}_{0}$, was around $0.28 \mathrm{~mm}$ /day for both experimental years. The mean peach crop coefficient, calculated as $K_{c}=K_{c b}+K_{e}$, was close to 0.66 (Fig. 7).

\subsection{Evapotranspiration: measured versus estimated by the FAO 56 approach}

Daily crop coefficients measured by the eddy covariance technique (0.4-0.6) were found to be around $25 \%$ lower than the estimated daily crop coefficients (0.66). A correlation between $\mathrm{ET}_{\mathrm{c}}$ and $\mathrm{ET}_{\mathrm{ec}}$ resulted in $\mathrm{ET}_{\mathrm{ec}}=0.77 \mathrm{ET}_{\mathrm{c}}\left(r^{2}=0.73\right)$, (Fig. 8), when 1998 and 1999 information are considered together. For field conditions, the use of the dual crop coefficient approach would lead to an overestimation of water

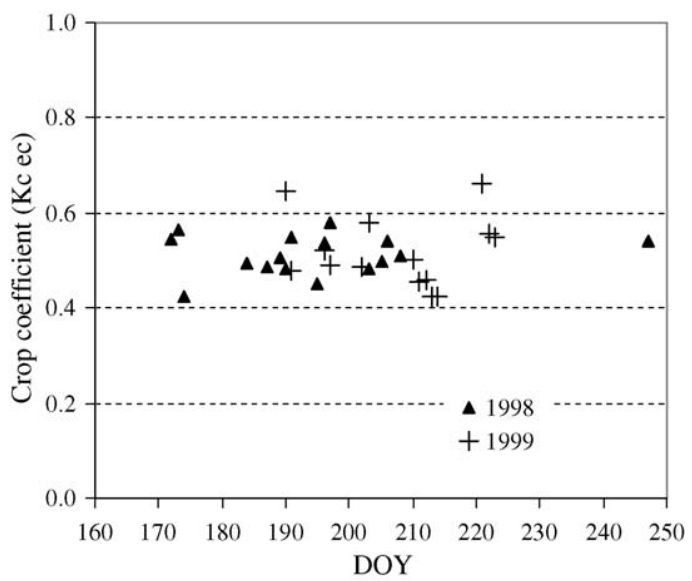

Fig. 6 - Crop coefficients obtained from evapotranspiration measurements with the eddy covariance technique. 

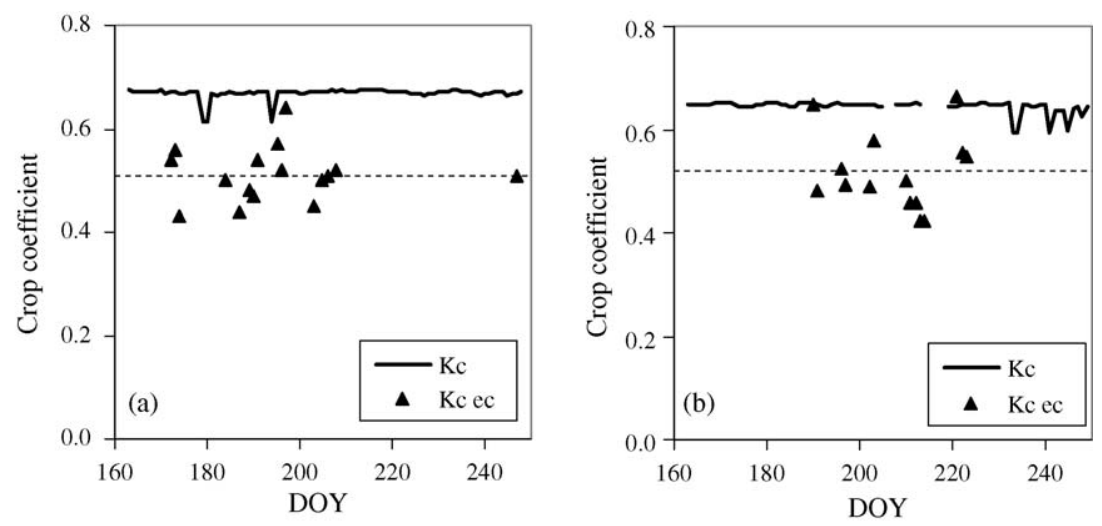

Fig. 7 - Crop coefficients measured with the eddy covariance technique $\left(K_{\mathrm{c}}\right.$ ec $)$ and estimated using the FAO 56 approach (Allen et al., 1998); the dotted lines represent mean $K_{c}$ ec; (a) 1998 and (b) 1999.

consumption by $30 \%$, corresponding to approximately $1200 \mathrm{~m}^{3} /$ (ha year).

Even if the estimated crop coefficients differ from the observed ones, they are closer to observations than previously tabulated values (Doorenbos and Pruitt, 1977), which are about 0.9 for orchards with $70 \%$ ground cover. Doorenbos and Pruitt (1977) refer to other crop conditions, such as young orchards with reduced ground cover where, for a minimum ground cover of $20 \%$, the maximum reduction in $K_{c}(35 \%)$ would lead to a final value of 0.75 (which is still higher than the measured $K_{c}$ values of the present study). Concerning drip irrigation, also in young orchards, but for light, sandy soils and with $30 \%$ ground cover, a possible reduction in $\mathrm{ET}_{\mathrm{c}}$ up to $60 \%$ is reported by the same authors. The conditions under study were similar to these, except for the fact that the trees were not expected to increase height or canopy volume, as they were pruned to maintain those dimensions and therefore expected to keep ground cover even when older. However, within the canopy volume the tree branch density and the number of leaves per

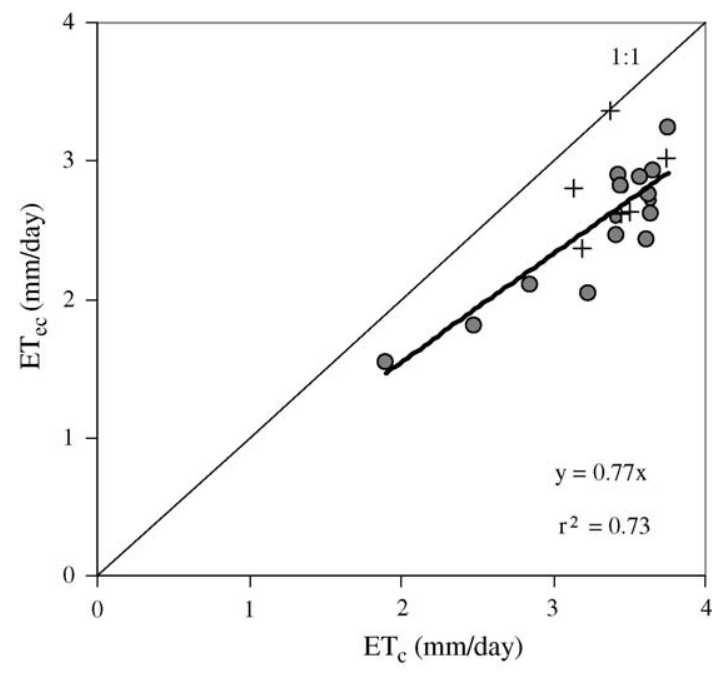

Fig. 8 - Comparison between evapotranspiration measured by the eddy covariance technique $\left(\mathrm{ET}_{\mathrm{ec}}\right)$ and crop evapotranspiration estimated by FAO methodology $\left(\mathrm{ET}_{\mathrm{c}}\right)$; circle, 1998; cross 1999.

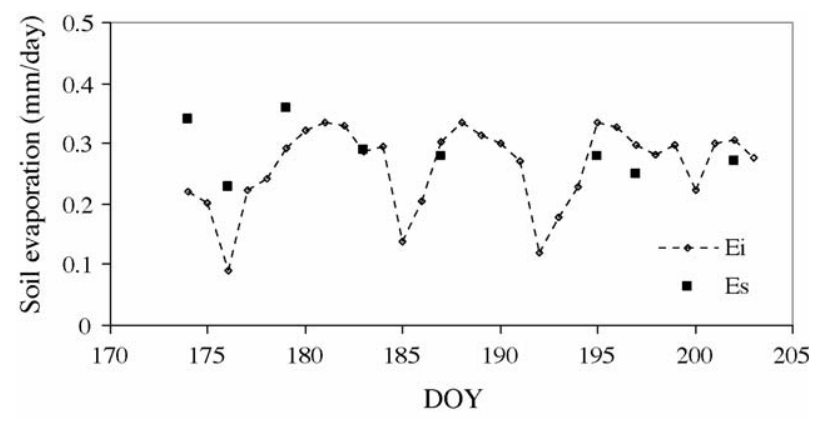

Fig. 9 - Estimates of soil evaporation by the FAO methodology procedures $\left(E_{i}\right)$ and measurements by lysimetry $\left(E_{s}\right), 1998$.

tree could increase with age until complete maturity, involving also a possible increase in LAI and tree transpiration, respectively. Nevertheless, in our conditions the fourth year of a peach orchard marks the beginning of the full production, and orchards have a short potential life (around 60\% have under 9 years).

The soil evaporation component in the $K_{c}$ estimated by the FAO 56 approach, $E_{i}$, showed a reasonable agreement with results from lysimeter measurements (Fig. 9, days after rain not included). Given this good agreement for the soil component, the overestimation in $K_{c}$ is probably due to an overestimation of plant transpiration. Daily simultaneous measurements of soil evaporation by lysimetry and evapotranspiration by eddy covariance showed that soil evaporation represented around $10 \%$ of $\mathrm{ET}_{\mathrm{ec}}$. This indicates that the mean value for $K_{\mathrm{cb}}$ should be around 0.45 , as average $K_{\mathrm{c}}$ ec is close to 0.5 . A reduction in $K_{\mathrm{cb}}$ adj should therefore be considered, reviewing the adjustment calculation procedure. A way of doing this can be by the reduction of $K_{c b}$ full. The calculation proposed by Allen et al. (1998) uses the maximum of $K_{c b}$ estimates (at peak plant size or height) as $K_{\mathrm{cb}}$ full. We suggest the use of a value for $K_{\mathrm{cb}}$ full close to the maximum measured value of $K_{\mathrm{cb}}$ in field conditions, as the value taken from FAO 56 seems too high for the experimental conditions met here. $K_{\mathrm{cb}}$ obtained in the field from $\mathrm{ET}_{\mathrm{ec}}$ varies between 0.38 and 0.59 , for 

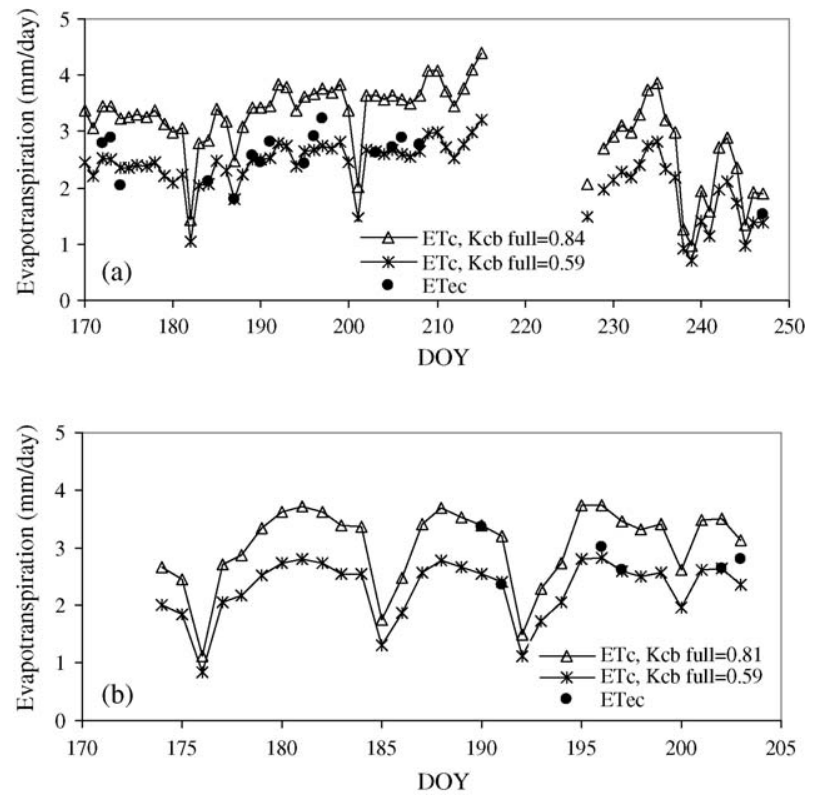

Fig. $10-\mathrm{ET}_{\mathrm{c}}$ as estimated by the FAO methodology procedures and using an improved $K_{\mathrm{cb}}$ full: (a) 1998 and (b) 1999 (ET $_{\text {ec }}$ from days without rain).

the period of measurements in 1998 and 1999. If a maximum value (0.59) for $K_{\mathrm{cb} \text { full }}$ is considered, $K_{\mathrm{cb}}$ adj would become 0.48 , leading to values of $\mathrm{ET}_{\mathrm{c}}$ that show a better agreement with $\mathrm{ET}_{\mathrm{ec}}$ (Fig. 10), as the $K_{\mathrm{c}}$ now (around 0.54) approaches the measured values.

\section{Conclusions}

For the young peach orchard under study, established on a sandy soil and drip irrigated, measured crop coefficients were 0.5 , which agrees well with data from a former study, for similar conditions. Comparatively, the crop coefficients estimated using the FAO 56 dual crop coefficient approach were higher (0.7, as an average).

Measuring ET and, simultaneously, the other components of the surface energy balance provides two alternative ways of determining ET, assuring a good check of the quality data. The energy balance of the surface has provided a good closure error for the energy balance equation, indicating a maximum error for ET of $10 \%$.

A good relationship $\left(r^{2}=0.95\right)$ has been obtained between soil heat flux and net radiation, providing a simple model to estimate $G$, for practical applications.

Soil evaporation was found to be close to $10 \%$ of ET. The soil component estimates in the crop coefficient were similar to measured values, indicating a discrepancy in the plant component. As the mean value of the crop coefficient was 0.5 , the basal crop coefficient was close to 0.45 . Although the chosen approach (the use of a basal crop coefficient for a sparse crop) seems adequate for orchard conditions, better estimates were found when the parameters used were modified, based on field measurements. The modifications concerned the $K_{\mathrm{cb}}$ full used in the FAO 56 approach, considering that it represents the maximum estimated $K_{\mathrm{cb}}$ during the midseason and, consequently, it could be estimated by the maximum value of $K_{\mathrm{cb}}$ observed in field measurements. However, additional data are still needed from more mature orchards established on various textured soils and irrigated by different methods in order to generalize these results.

\section{Acknowledgements}

The authors wish to thank Dr. Richard Allen for his comments on the application of FAO 56 methodology, Dr. Charles Valancogne for his contribution for soil heat flux, net radiation and wind direction measurements and Professor Jorge Soares David for the text reviewing.

The work presented was supported by the following entities: (1) Project Innovative biological indicators to improve the efficiency of water and nitrogen use and fruit quality in tree crops (FAIR-CT 95-0030), Program FAIR-EU, (2) Foundation for Science and Technology, Portugal, and ESF in the third Framework Programme of RTD-EU (Ph.D. and Post-doc fellowships), (3) ICCTI, Portugal/French Embassy Protocol and (4) Project WATERUSE Evaluation of Alternative Techniques for Determination of Water Budget Components in Water Limited Heterogeneous Land Use Systems, fifth Framework Programme of RTD-EU (EVK1-2002-00079).

\section{R E F E R E N C E S}

Allen, R.G., 2000. Using the FAO-56 dual crop coefficient method over an irrigated region as part of an evapotranspiration intercomparison study. J. Hydrol. 229, 27-41.

Allen, R.G., Pereira, L.S., Raes, D., Smith, M., 1998. Crop evapotranspiration. Guidelines for computing crop water requirements. FAO Irrigation and Drainage Paper No. 56. FAO, Rome, Italy.

Allen, R.G., Pruitt, W.O., Raes, D., Smith, M., Pereira, L.S., 2005. Estimating evaporation from bare soil and the crop coefficient for the initial period using common soils information. J. Irrig. Drain. Eng. 131, 14-23.

Baldocchi, D.D., Hicks, B.B., Meyers, T.P., 1988. Measuring biosphere-atmosphere exchanges of biologically related gases with micrometeorological methods. Ecology 69, 1331-1340.

Berbigier, P., Bonnefond, J.M., Loustau, D., Ferreira, M.I., David, J.S., Pereira, J.S., 1996. Transpiration of a 64 -year old maritime pine stand in Portugal. 2. evaporation and canopy stomatal conduction by an eddy covariance technique. Oecologia 107, 43-52.

Burman, R.D., Nixon, P.R., Kimberly, I.D., Pruitt, W.O., 1980. Water requirements. In: Jensen, M.E. (Ed.), Design and Operation of Farm Irrigation Systems. ASAE Monogr. 3, pp. 189-232.

Casa, R., Russell, G., Lo Cascio, B., 2000. Estimation of evapotranspiration from a field of linseed in central Italy. Agric. For. Meteorol. 104, 289-301.

Conceição, N.M.S., 2001. Evaporação directa em solo arenoso num pomar de pessegueiros com rega gota-a-gota diária. In: Relatório do trabalho final de curso, Universidade Técnica de Lisboa, Instituto Superior de Agronomia, Lisboa, 104 pp.

Daamen, C.C., Simmonds, J.S., Wallace, J.S., Laryea, K.B., Sivakumar, M.V.K., 1993. Use of microlysimeters to measure 
evaporation from sandy soils. Agric. For. Meteorol. 65, 159-173.

Doorenbos, J., Pruitt, W.O., 1977. Crop water requirements. FAO Irrigation and Drainage Paper No. 24 (rev.) FAO, Rome, Italy.

Dragoni, D., Lakso, A.N., Piccioni, R.M., 2004. Transpiration of an apple orchard in a cool humid climate: measurement and modeling. Acta Hort. 664, 175-180.

Ferreira, M.I., Valancogne, C., Daudet, F.-A., Ameglio, T., Michaelsen, J., Pacheco, C.A., 1996. Evapotranspiration and crop water relations in a peach orchard. In: Camp, C.R., Sadler, E.J., Yoder, R.E. (Eds.), Evapotranspiration and Irrigation Scheduling. ASE, San Antonio, TX, pp. 60-68.

Ferreira, M.I., Valancogne, C., Michaelsen, J., Pacheco, C.A., Ameglio, T., Daudet, F.-A., 1997. Evapotranspiration, water stress indicators and soil water balance in a Prunus persica orchard, in central Portugal. Acta Hort. 449 (2), 379-384.

Giovannini, D., Monastra, F., 1998. Tipologie d'impianto e forme di allevamento per la peschicoltura meridionale. In: Sansavini, S., Errani, A. (Eds.), Frutticoltura ad alta densità. Impianti, forme di allevamento, e tecniche di potatura. Edagricole, Bologna, pp. 217-235.

Grappadelli, L.C., Sansavini, S., 1998. Forme di allevamento, efficienza degli impianti e qualità delle pesche. In: Sansavini, S., Errani, A., (Eds.), Frutticoltura ad alta densità. Impianti, forme di allevamento, e tecniche di potatura. Edagricole, Bologna, pp. 191-216.

Kanemasu, E.T., Steiner, J.L., Rasmussen, V.P., Bagley, J., 1979. Estimating water requirements for corn with a programmable calculator. Bull.15 (revised October 1979), Agricult. experim. station. Kansas State University, Manhattan, USA.

Kizer, M.A., Elliot, R.L., 1991. Eddy correlation systems for measuring evapotranspiration. Trans. ASAE 34, 387-392.

Kustas, W.P., Prueger, J.H., Humes, K.S., Starks, P.J., 1999. Estimation of surface heat fluxes at field scale using surface layer versus mixed-layer atmospheric variables with radiometric temperature observations. J. Appl. Meteorol. 38, 224-238.

Lascano, R.J., 2000. A general system to measure and calculate daily crop water use. Agron. J. 92, 821-832.

Laubach, J., Raschendorfer, M., Kreilein, H., Gravenhorst, G., 1994. Determination of heat and water vapour fluxes above a spruce forest by eddy correlation. Agric. For. Meteorol. 71, 373-401.

Lee, X., Black, T.A., 1993. Atmospheric turbulence within and above a douglas-fir stand. Part II. Eddy fluxes of sensible heat and water vapour. Bound.-Layer Meteor. 64, 369-389.

Leclerc, M.Y., Thurtell, G.W., 1990. Footprint prediction of scalar fluxes using a Markovian analysis. Bound.-Layer Meteor. 52, 247-258.

Paço, T.A., Conceição, N., Ferreira, M.I., 2004. Measurements and estimates of peach orchard evapotranspiration in Mediterranean conditions. Acta Hort. 664, 505-512.
Rana, G., Katerji, N., de Lorenzi, F., 2005. Measurement and modeling of evapotranspiration of irrigated citrus orchard under Mediterranean conditions. Agric. For. Meteorol. 128, 199-209.

Ritchie, J.T., 1972. Model for predicting evaporation from a row with incomplete cover. Water Resour. Res. 8, 1204-1213.

Schuepp, P.H., Leclerc, M.Y., MacPherson, J.I., Desjardins, R.L., 1990. Footprint prediction of scalar fluxes from analytical solutions of the diffusion equation. Bound.-Layer Meteor. 50, 355-373.

Simpson, I.J., Thurtell, G.W., Neumann, H.N., Hartog, G.D., Edwards, G.C., 1998. The validity of similarity theory in the roughness sublayer above forests. Bound.-Layer Meteor. 87, 69-99.

Snyder, R.L., Paw, U.K.T., Duce, P., Spano, D., Ferreira, M.I., do Paço, T.A., Connel, J.H., 2000. Measuring tree and vine ET with eddy covariance. Acta Hort. 537 (1), 53-60.

Tanner, C.B., Jury, W.A., 1976. Estimating evaporation and transpiration from a row crop during incomplete cover. Agron. J. 68, 239-243.

Tanner, B.D., Swiatek, E., Greene, J.P., 1993. Density fluctuations and use of the krypton hygrometer in surface flux measurements. In: Proceedings of the National Conference on Irrigation and Drainage Engineering, Park City, UT, ASCE, New York, NY, July 21-23, 1993.

Tanner, B.D., Tanner, M.S., Dugas, W.A., Campbell, E.C., Bland, B.L., 1988. Evaluation of an operational eddy correlation system for evapotranspiration measurements. In: Campbell Scientific (Ed.), Eddy correlation instrumentation (Models KH20 and CA27). Collected papers, version 1 (1.88). Logan, UT.

Testi, L., Villalobos, F.J., Orgaz, F., 2004. Evapotranspiration of a young irrigated olive orchard in southern Spain. Agric. For. Meteorol. 121, 1-18.

Thompson, M.A., Campbell, D.I., Spronken-Smith, R.A., 1999. Evaporation from natural and modified raised peat bogs in New Zealand. Agric. For. Meteorol. 95, 85-98.

Twine, T.E., Kustas, W.P., Cook, D.R., Houser, P.R., Meyers, T.P., Prueger, J.H., Starks, P.J., Wesely, M.L., 2000. Correcting eddy-covariance flux underestimates over a grassland. Agric. For. Meteorol. 103, 279-300.

Webb, E.K., Pearman, G.L., Leuning, R., 1980. Correction of flux measurements for density effects due to heat and water vapour transfer. Q. J. R. Meteorol. Soc. 106, 85-100.

Wilson, K., Goldstein, A., Falge, E., Aubinet, M., Baldocchi, D., Berbigier, P., Bernhofer, C., Ceulemans, R., Dolman, H., Field, C., Grelle, A., Ibrom, A., Law, B.E., Kowalski, A., Meyers, T., Moncrieff, J., Monson, R., Oechel, W., Tenhunen, J., Valentini, R., Verma, S., 2002. Energy balance closure at FLUXNET sites. Agric. For. Meteorol. 113, 223-243.

Wright, J.L., 1982. New evapotranspiration crop coefficients. J. Irrig. Drain. Div. 108 (IR2), 57-74. 